\title{
IPO Pricing and Dealers' Interaction: A Stochastic Frontier Approach
}

\author{
Marco Cucculelli ${ }^{1}$, Manuela Geranio ${ }^{2}$, Camilla Mazzoli ${ }^{3} \&$ Sabrina Severini $^{3}$ \\ ${ }^{1}$ Department of Economics, Università Politecnica delle Marche, Ancona, Italy \\ ${ }^{2}$ Department of Scienze Aziendali, University of Bergamo, Bergamo, Italy \\ ${ }^{3}$ Department of Management, Università Politecnica delle Marche, Ancona, Italy \\ Correspondence: Camilla Mazzoli, Department of Managament, Università Politecnica delle Marche, Ancona, \\ 61121, Italy.
}

Received: November 11, 2020

Accepted: November 30, 2020 Online Published: December 18, 2020

doi:10.5539/ibr.v14n1p1

URL: https://doi.org/10.5539/ibr.v14n1p1

\begin{abstract}
This study investigates the impact of ongoing relationships between underwriters and institutional investors on Initial Public Offerings (IPO) pricing. Differently from previous studies that are focused on allocations of underpriced shares we propose a model of primary market pricing in which the incomplete adjustment of the offer price to its maximum achievable level depends on the intensity of interactions that occurred between players in the years before the IPO. Using a stochastic frontier approach on a sample of 1677 US IPOs between 2000 and 2016 the paper shows that the more investment banks and investors regularly work together the more the IPO offer price is set closer to the fair value of the issuing firm. This analysis helps to disentangle the ambiguous effects of underwriters' discretion on IPO primary market pricing when bookbuilding is used. We then support the idea that banks can maximize value to issuers by fostering a regular clientele of investors.
\end{abstract}

Keywords: initial public offerings, stochastic frontier, primary markets pricing, interactions, bookbuilding

\section{Introduction}

\subsection{Motivation for the Study}

An initial public offering (IPO) is launched when a firm goes public for the first time. One of the main problems associated with the IPO is pricing the shares issued by the listing company. Setting the price of an IPO is difficult because the firm is new in the market and accordingly no trading history exists nor does the firm have any remarkable analyst coverage (See \& Rashid, 2011).

Existing literature on IPO pricing in primary markets (Ibbotston \& Ritter, 1995; Ritter \& Welch, 2002; Roosenboom, 2012) suggests that the price is set deliberately low by the investment bank thus allowing a large amount of money to be left on the table for the issuing firm. Underwriters might not raise the price to full market value for several reasons: adverse selection and moral hazard problems (Baron, 1982; Rock, 1986) the burden of market making (Benveniste, Busaba \& Wilhelm, 1996; Chowdhry \& Nanda, 1996) the risk of lawsuits (Lowry \& Shu, 2002) reputation concerns (Beatty \& Ritter, 1986; Carter \& Manaster, 1990) institutional and country-specific issues (Engelen \& van Essen, 2010) or the efforts required for limiting aftermarket stabilization of transactions (Beatty \& Ritter, 1986; Ibbotston, Sindelar \& Ritter, 1988; Aggarwal, 2003). Moreover, at this stage underwriters and institutional investors who repeatedly work together during different IPOs might easily collude thus deliberately tuning the offer price according to their prevailing interests (Ljungqvist \& Wilhelm, 2002).

Several studies offer different views on the role played by repeated interactions on initial returns. Consistent with bookbuilding theories (Benveniste \& Spindt, 1989; Benveniste \& Wilhelm, 1990; Spatt \& Srivastava, 1991; Sherman \& Titman, 2002) underwriters that sell repeatedly to the same investors can take advantage of their vis-à-vis information production thus tuning the offer price upward with the promise of priority allocations in future underpriced IPOs. Similarly, the transparency of the IPO mechanism in some countries provides information benefits to investors who generate a larger demand that in turn positively affects IPO price (Neupane \& Poshakwale, 2012).

By contrast according to agency-based explanations repeated interactions bring about a potential conflict of interest because large underpriced allocations might be given to regular investors in exchange for future 
brokerage commissions (Reuter, 2006). Consistent with this profit-sharing view banks can use their monopsony power to allocate underpriced shares to investors that can pass on profits and benefits to banks (Note 1) (Ritter, 1984; Chalk \& Peavy, 1987; Reuter, 2006) thus supporting a conflict of interest motivation (Note 2).

The extant literature does not solve the puzzle of whether the practice of bookbuilding increases the price accuracy or the conflict of interest. Moreover, events occurred since the dot-com period showed that quid pro quo arrangements - where preferential allocations are given to rent-seeking investors (Liu \& Ritter, 2010) might have taken place. Therefore, doubts remain as to how the primary market works in favour of issuing firms (Davis, Jurich, Roseman \& Watson, 2018) so that regulators now require underwriters to implement specific policies to address conflicts of interest (Jenkinson, Jones \& Suntheim, 2018).

To overcome the limitations of the existing literature and contribute to the analysis of the effects of the market interactions on the IPO results we propose a model of primary market pricing that exploits the incomplete adjustment of the offer price with respect to the fair offer price. Taking inspiration from the extant literature on deliberate premarket underpricing (see Reber \& Vencappa, 2016) we focus on the interactions between underwriters and institutional investors as a source of variability in the definition and the revision of the offer price in primary markets. Contrary to previous studies that are mainly focused on how underwriters favour institutions they have previously worked with in terms of greater participation (Binay, Gatchev \& Pirinsky, 2007) and allocation of underpriced shares (Reuter, 2006; Ritter \& Zhang, 2007; Goyal \& Tam, 2013) our study analyses the use of information collected through repeated dealings on pricing the IPO. More specifically we analyse to what extent the IPO offer price is set deliberately low in the primary market when coalitions exist between investment banks and regular investors. We first estimate the firm's intrinsic value - i.e. the maximum price achievable given the firm characteristics and fundamentals - using a Stochastic Frontier Approach (SFA); we then model the variance of the inefficient error component by including different measures of interaction between investment banks and institutional investors occurred in the years before the IPO. The relationship measure we here introduce is based on the frequency of repeated interactions between these agents bearing in mind that the higher the interactions the greater the information collected by underwriters. Such relationship measure is then put into a relationship with the primary market pricing to test to what extent it is efficiently used in pricing the IPO firm's shares rather than favouring institutions giving a large amount of underpriced shares. Based on bookbuilding theories (Benveniste \& Spindt, 1989; Benveniste \& Wilhelm, 1990; Spatt \& Srivastava, 1991; Sherman \& Titman, 2002) we expect that the adjustment of the offer price to the firm's intrinsic value is shaped by the intensity of the underwriters-investors relationships in that information gathered during bookbuilding is used by underwriters to set prices close to the fair market value rather than to favour institutional investors who collaborate in IPOs. In other terms, we support the idea that banks dealing repeatedly with the same investors are likely to develop a reputation for fair dealing. When all possible circumstances of an asset sale cannot be predicted, reputation can help the bank to bridge the gaps in "incomplete" contracts (Wilhelm, 2005). Moreover, the apparently unfavourable outcome for institutional investors that comes out from this mechanism might be compensated by a quid pro quo expected arrangement to participate in future issues. Based on a sample of 1677 US IPOs between 2000 and 2016 we find that the intensity of interaction between underwriters and investors in the years before the IPO explains the level of price accuracy. Our results show that the offer price is set closer to the fair price when more interactions occur before the IPO. More specifically when different time frames of underwriters-investors interactions are considered (a quarter, one year, two years and three years before the IPO), the impact of repeated interactions on the price accuracy is positive and more significant for long lasting relationships (more than one year), whereas the influence is weaker for shorter intervals. The core of this finding is that relationships matter and even more importantly relationships might be a benefit for issuers as the price is closer to its optimal value.

The rest of the paper is organized as follows. In Section 2 we present the existing literature and our related hypotheses. Section 3 summarizes the data and the methodology employed for the empirical analysis. Results and conclusions are presented respectively in Section 4 and 5.

\subsection{Literature Review}

IPOs are always characterized by information asymmetry mainly because of issuing firms that are new to the market and investors having limited knowledge about them (See \& Rashid, 2011). The going-public decision represents a typical situation in which the value of the firm must be established without referring to a market value (Kim \& Ritter, 1999). Consequently, the correct valuation of the issuing firm that might allow to set IPO offer prices efficiently depends on the due diligence and bookbuilding process in the primary market. Because the issuing firm is informationally opaque to investors and information is costly (Note 3), the issuer retains a (relationship) investment bank to act as its agent in pricing and marketing the new stocks (Ibbotson \& Ritter, 
1995; Calomiris \& Pornrojnangkool, 2009; DeYoung \& Li, 2019). This makes multiple agency problems likely to come out at the IPO pricing stage (Baron, 1982). Agency-based studies have documented that the IPO share price can be set deliberately low in the primary market to allow for a large amount of money to be left on the table to the disadvantage of the issuing firm or the selling shareholders (Hanley, 1993; Ritter \& Welch, 2002). Most of these studies take their cue from the partial adjustment phenomenon (Hanley, 1993) and measure the disadvantage for the issuer in terms of underpricing. Gondat-Larralde and James (2008) suggest that banks underprice each offering to the extent necessary to make remaining in the coalition the most profitable choice for informed investors. Based on a sample of 3197 IPOs occurred in the period between 1980 and 2000, Binay, Gatchev and Pirinsky (2007) find that their measure of relationship participation positively affects the level of underpricing thus arguing that regular investors benefit from economically significant favouritism to the detriment of issuing firms.

This literature which supports the existence of agency-related problems between underwriters and regular investors is opposed by a stream of literature usually referred to as 'bookbuilding theory'. Scholars in this branch maintain that interactions occurring between banks and funds in the primary market are likely to increase the information production process and lead to a more efficient pricing of the IPO which is positive for the issuing firm. In particular, some authors argue that banks obtain valuable information from regular investors on the expected demand for the IPO (Benveniste \& Spindt, 1989; Sherman \& Titman, 2002) and use this information to price the offer more accurately even using peer networks to produce information (Chuluun, 2015). In this context the price mechanism of bookbuilding has a twofold goal: 1) to build a regular investor clientele and 2) to price and market the issue more efficiently through the non-bidding indication of interest given by institutional investors. This repeated game setup benefits issuers by reducing underpricing but it also helps investors by increasing their profits from participation in multiple offerings. Moreover, as suggested in Busaba, Benveniste and Guo (2001) and Benveniste, Busaba, and Wilhelm (2002) having the option to walk away in bookbuilding practice leads to better offer pricing because the underwriter bumps up the price to prevent withdrawal (Busaba, Liu \& Restrepo, 2019).

Both the above approaches i.e. bookbuilding-based studies and agency-based studies have a methodological weakness as they extensively use underpricing as a key variable. As underpricing reflects the difference between the market price and the offer price it is highly likely that it might be influenced by the long-term or short-term attitude of investors, by the price support operated by the investment banks, by the media echo received by the offer and also by the desire of entrepreneurs' for post-IPO control (Luo \& Ouyang, 2014). As a consequence, such a pricing measure is not totally suitable to draw primary market dynamics.

Starting from Hunt-McCool, Koh and Francis (1996) studies based on a stochastic frontier approach have been proposed to deal with the bias that the offer price can be set deliberately low in the primary market (Koop \& $\mathrm{Li}$, 2001; Francis \& Hasan, 2001; Chen, Hung \& Wu, 2002; Chan, Wu \& Kwok, 2007; Meng, Zhang \& Zou, 2016). Results from these studies where the difference between the efficient and the actual offer price is split into a primary market (deliberate underpricing) component and a secondary market (misevaluation) component (Note 4) show that the deliberate underpricing is the dominant component that makes up initial return. Specifically, Reber and Vencappa (2016) find that the presence of some features like: underwriter fees, lock-up agreements, venture capital backing have positive impacts on deliberate premarket underpricing thus providing a partial solution to the issue of the divergence between the efficient and the actual offer price (Johnston, Madura \& Harper 2005). However, despite the numerous underpricing factors involved in the analysis the interactions between the main players of an IPO as a source of variability in the setting and the revisions of the offer price in primary markets has not been explicitly considered. Along this line we analyse to what extent the IPO offer price is set deliberately low in the primary market with respect to the firm's intrinsic value when coalitions between investment banks and regular investors exist in the primary market. Specifically, we put forward the following hypothesis:

Hyp (1): the larger the number of interactions in the years before the IPO the closer the offer price is set to the intrinsic value of the issuing firm.

This hypothesis is based on the intuition that banks dealing repeatedly with the same investors are likely to develop a reputation for fair dealing which helps in dealing with complex cases where it is impossible to specify all possible contingencies in an asset sale (Wilhelm, 2005).

To consider the dynamic structure of the deals we explore the pricing-relationship between parties over time. We hypothesize that the prediction of the dynamic information model is confirmed when we consider interactions occurred at least one year before the IPO or more (Hyp (1)). By contrast we expect that 'arm's length ties' i.e. 
relationships built in the quarter before the IPO (Daily, Certo, Dalton \& Roengpitya, 2003; Granovetter, 2005) are not able to influence IPO price setting and have no impact on the level of price accuracy. In details we test the following hypothesis:

Hyp (2): the smaller the time frame of the interactions between underwriters and institutional investors the less effective they on the price accuracy

To sum up only collaborations that are repeated over time and for a significant span of time can create enough trust to generate embedded ties on which resource pooling and cooperation can be based and that in turn support information production (Baker, 1990; Uzzi, 1999; Uzzi \& Gillespie, 1999; Gulati \& Higgins, 2003).

\section{Data and Methods}

\subsection{Data and Sample Selection}

We collected our sample of 2925 US IPOs from the Thomson One Deals database (TOD). We searched for all the IPOs occurring on the NASDAQ and NYSE from January 2000 to December 2016. Following Ritter \& Zhang (2007) we excluded IPOs with the following characteristics: offer price below \$5 (Note 5), non-common shares, closed-end funds filings by foreign-domiciled firms Master Limited Partnerships (MLPs), American Depository Receipts (ADRs) and Real Estate Investment Trusts (REITs) (Note 6). Underwriters-institutional investors relationships have been redesigned using the name of lead managers from the TOD and the data about institutional investors' participation in $13 \mathrm{~F}$ institutional ownership. We used the first reported holding by investors at the end of the offering quarter as a proxy for participation in the IPO since actual allocation is not publicly available (Reuter, 2006; Ritter \& Zhang, 2007; Field \& Lowry, 2009; Goyal \& Tam, 2013). We also included information regarding financial statements of issuing firms from Compustat (Note 7). Information concerning market conditions and US underwriters' reputations rankings were retrieved from Jay Ritter's website. Our final sample excluding observations with missing values on the variables of interest consisted of 1677 US IPOs.

\subsection{The Empirical Model}

The Stochastic Frontier Analysis (SFA) combines an ordinary linear regression model with a composite error term (Aigner, Lovell \& Schmidt, 1977; Jondrow, Lovell, Materov \& Schmidt, 1982). The error term can be broken down into a symmetric error term which represents the usual stochastic error terms and an asymmetric error component. This non-idiosyncratic disturbance represents a systematically negative bias due to some inefficient pars. Widely used in estimation of production efficiency this methodology has been adopted also in pricing IPOs (Hunt-McCool et al., 1996). Under the IPO pricing scenario, the SFA allows an estimation of the maximum or "efficient" offer price that would prevail in a situation of full information given the firm's characteristics.

$$
\begin{gathered}
Y_{i}=f\left(X_{i} \beta\right)+\varepsilon_{i} \\
\varepsilon_{i}=v_{i}-u_{i} \\
v_{i} \sim N\left(0 ; \sigma_{v}^{2}\right) \\
u_{i} \sim N^{+}\left(0 ; \sigma_{u}^{2}\right)
\end{gathered}
$$

Typically in the IPO pricing context $\mathrm{Y}$ is the observed offer price of the issuer $\mathrm{i} ; \mathrm{X}$ is a vector of the observed firm's characteristics; $\beta$ is a vector of parameters to be estimated; $v_{i}$ is the symmetric error component with a normal distribution and $\mathrm{u}_{\mathrm{i}}$ is the asymmetric error term with a half-normal distribution truncated at zero (Note 8). In other terms for a given IPO a point on the frontier represents the unobserved "fair" offer price that is the maximum price that investors are willing to pay given a set of "pricing factors" included in the vector of input X. The stochastic frontier assumes that deviations of actual prices from the maximum price, captured by the one-sided error term, are due from some "economic inefficiency". As pointed out in Hunt-McCool et al. (1996) the advantage of using this method in IPO pricing is to avoid using aftermarket information to compute IPO prices in the primary market.

Reber and Vencappa (2016) provided an additional contribution by modelling the exogenous factors that influence the gap from the frontier. In other terms, when fitting the IPO offer price frontier, they also explicitly model the heteroscedasticity of the one-sided error term (Kumbhakar \& Lovell, 2003). Empirically the one-sided error variance is modelled together with the frontier as: 


$$
\sigma_{u_{i}}^{2}=f\left(Z_{i} \gamma\right)
$$

Where $\sigma_{u}^{2}$ gives the dimension of the deliberate premarket underpricing and $\mathrm{Z}$ is the vector of parameters to be estimated. In the conditional variance model the vector $\mathrm{Z}$ of parameters to be estimated includes a set of variables capturing the information asymmetry such as: the market conditions at the time of the IPO the deal characteristics the presence of third-party certification and more generally the uncertainty surrounding the IPO. Our model focuses on the type and intensity of the interactions between underwriters and institutional investors before the IPO as predictors of the distance of the price set from the frontier. In details we expect to observe deviations between the actual and optimal price correlated to the nature and intensity of the interaction between players before the IPO.

\subsection{Measurement of Variables}

We make use of the offer price per share as the dependent variable. Explanatory variables are classified into two categories: "pricing factors" and "deliberate premarket factors". As for the first category i.e. pricing factors variables included in the empirical model are related to firm's characteristics and account for the profitability risk and growth potentialities of the issuing firm. These factors are indicated as main drivers of the offer price from the standard financial theory. Moreover, we followed Koop and Li (2001) by including data from the accounting period before the IPO as proxies for future profitability. As for the second category i.e. "deliberate premarket factors" these variables include factors that explain the distance of the actual price from the maximum achievable offer price. This category involves exogenous factors that do not depend on the firm's potential performance or its intrinsic characteristics but that can influence the magnitude of the deliberate premarket underpricing (Reber \& Vencappa, 2016).

We used standard financial theory to select the variables to be included in the estimate of the potential maximum offer price. This theory posits that investors use issuing firm's characteristics such as profitability riskiness and extent of asymmetric information to judge the issuer's value (Myers \& Majluf, 1984). We proxied the future performance of cash flow using the logarithm of Earnings Before Interest and Taxes (EBIT) in the accounting period before the IPO (Note 9). We prefer using EBIT instead of cash flows because the latter are subject to higher annual volatility; we also use EBIT instead of EPS because the latter is subject to manipulation by managers ("window-dressing") before the offering is launched (Jain \& Kini, 1994; Teoh, Welch \& Wong, 1998; Heaton, 2002). To account for negative EBIT values, we added a dummy variable coded one if the firm had a negative EBIT in the accounting period before the IPO (NEG_EBIT) and zero otherwise. By doing this we avoided losing relevant information regarding the negative earnings performance because of the logarithm transformation. Following Hunt-McCool et al. (1996) and Chen et al. (2002) we controlled for firm size using the logarithm of the book value of the asset in the accounting period before the offer (FIRM_SIZE). To account for the riskiness of the firm we computed the leverage (LEV) as the logarithm of long-term debt scaled by total assets in the accounting period before the IPO (Habib \& Ljungqvist, 2001). As in Peng and Wang (2007) we expected a negative correlation between debt level and the IPO market price. To consider the potential role of asymmetric information we added an industry dummy to account for the fact that firm's value is unlikely to be uniformly distributed across the industry (Ritter, 1991). In line with previous studies we allocated IPO firms into 12 two-digit SIC industry sectors. The presence of different sectors allowed us to take into consideration not only differences in riskiness but also in growth opportunities. Table 1 provides a detailed review of all the variables that were used in this the study along with the data sources.

We borrowed explanatory variables from the IPO pricing literature to serve as the deliberate premarket factors (e.g. Hanley, 1993; Hunt-McCool et al., 1996; Carter, Dark \& Singh, 1998; Wu \& Kwok, 2003). We included in this category variables that can explain the deviation of the offer price from the maximum achievable one. In other terms we controlled for market features that in a competitive primary market might induce underwriters to deliberately tune the offer price downward to avoid the risk of IPO failure.

We used (the logarithm of 1 plus) firm AGE as a proxy for a reduction in the ex-ante uncertainty (Ritter, 1987) and the proportion of stocks owned by insiders (EQ_RET) as a measure of the risk characteristics of the IPO that are negatively related to the offer price (Beatty \& Ritter, 1986). As for the signalling effect on the IPO firm value we argue that the larger the equity retained the smaller the distance from the fair offer price for an IPO (Bradley \& Jordan, 2002; Loughran \& Ritter, 2004; Lowry \& Murphy, 2007) (Note 10). 
Table 1. Variables: description and sources

\begin{tabular}{|c|c|c|c|}
\hline & Variable & Source & Description of variable \\
\hline $\begin{array}{l}\text { Dependent } \\
\text { variable }\end{array}$ & OFFER PRICE & Thomson & Offer price per share in U.S.\$ \\
\hline \multicolumn{4}{|c|}{ Panel A: Pricing factors } \\
\hline & EBIT & Compustat & $\begin{array}{l}\text { Earnings before interest and taxes in the accounting period } \\
\text { before IPO }\end{array}$ \\
\hline & NEG_EBIT & Compustat & $\begin{array}{l}\text { Dummy variable equal to one if firm has negative EBIT in } \\
\text { the accounting period before IPO }\end{array}$ \\
\hline & FIRM_SIZE & Compustat & Total assets in the accounting period before the IPO \\
\hline & LEV & Compustat & $\begin{array}{l}\text { Long-term debt scaled by total assets in the accounting } \\
\text { period before the IPO }\end{array}$ \\
\hline & INDUSTRY & Compustat & Industry sector classification at the two-digit SIC level \\
\hline
\end{tabular}

Panel B: Deliberate premarket factors

\begin{tabular}{|c|c|}
\hline OFFER_SIZE & Thomson \\
\hline UW_REP & $\begin{array}{l}\text { Jay Ritter } \\
\text { Web site }\end{array}$ \\
\hline HOT_COLD & $\begin{array}{l}\text { Jay Ritter } \\
\text { Web site }\end{array}$ \\
\hline EQ_RET & Thomson \\
\hline FEE & Thomson \\
\hline LOCK-UP & Thomson \\
\hline AGE & $\begin{array}{l}\text { Jay Ritter } \\
\text { Website }\end{array}$ \\
\hline IPO_DEM & Thomson \\
\hline R_Q & Thomson \\
\hline R_1Y & Thomson \\
\hline R_2Y & Thomson \\
\hline
\end{tabular}

IPO Gross proceeds scaled by total assets in the accounting period before the IPO

\section{Underwriter reputation rank}

Net number of IPOs (exclude penny stocks units closed-end funds etc) in the month before the issue date

Logarithm $\left(1+\frac{\text { Secondary shares retained }}{\text { Shares offered }}\right)$ where Secondary

shares retained $=$ Share Outstanding - Total shares sold

Underwriting fees in U.S.\$ million

Dummy variable coded one if the flotation prospectus discloses the presence of a 'lock-up' agreement else coded zero.

Logarithm (1+firm age) where firm age is the number of years between the date the company was founded and the IPO date

Price adjustment from the midpoint of the filing price range to the offer price (in percent)

Average number of relationships between underwriter and investors in the quarter before the IPO

Average number of relationships between underwriter and investors in the year before the IPO

Average number of relationships between underwriter and investors in the two years before the IPO

Average number of relationships between underwriter and investors in the three years before the IPO

Note. Data sources include Thomson One Deal Compustat Jay Ritter's web site [http://bear.warrington.ufl.edu/ritter/ipodata.htm]. Formally we used the logarithmic transformation of all the input variables except for the dummy industries variables the underwriter's ranking the hot and cold indicator the IPO demand and the relationship measure.

We use the logarithm of the amount of gross proceeds scaled by total assets in the accounting period before the IPO to account for the offer size (OFFER_SIZE) and as a signalling variable. We controlled for the size effect because it is reasonable to expect that larger firm size implies less uncertainty better operation conditions and higher efficiency (Peng \& Wang, 2007). In line with Carter and Manaster (1990) we included the variable underwriter reputation (UW_REP). Generally low risk firms attempt to reveal their low risk characteristic to the market by selecting a highly prestigious underwriter: the more highly ranked the underwriter is the higher the efficiency achieved in price setting. This means that if the firm is followed by underwriters with a good 
reputation the offer price is expected to be set closer to the true value of the firm. We used the logarithm of fee (FEE) as a proxy for information risk because underwriters ask for a higher commission when facing more severe asymmetric information problems (Hughes, 1986; Meng et al., 2016).

We accounted for the market condition by including a hot and cold market indicator (HOT_COLD). This variable represents the net number of IPOs launched in the month before the issue date (excluding penny stocks units closed-end funds etc.). We used a dummy variable for the presence of lock-up agreements (LOCK-UP) which is a commitment that prohibits firm insiders from selling shares in the aftermarket for a specified period (it may vary from ninety days to two years in the U.S. market). Since investors face a lower 'moral hazard' problem when reselling is prohibited, we expect the demand for shares with a lock-up agreement to be higher than shares without (Brav \& Gompers, 2003;Arthurs, Hoskisson, Busenitz \& Johnson, 2008). This is (Bradley, Jordan, Yi \& Roten, 2001; Field \& Hanka, 2001). To better understand the role of regular investors in the bookbuilding process we also controlled for the IPO demand (IPO_DEM) revealed during the bookbuilding by using the price adjustment from the midpoint of the filing price range to the offer price (Binay et al., 2007; Chan et al., 2007) (Note 11). Following the argument proposed by Benveniste and Spindt (1989) and later empirically tested by Hanley (1993) we expected high (low) demand to reveal positive (negative) information that causes the offer price to be adjusted upward (downward). The intuition behind this hypothesis is that IPOs are not fully priced by underwriters because of the uncertainty they face as to demand for new shares (Note 12). Therefore, to increase the probability of success and to clear the aftermarket the investment banker sets the offer price deliberately low. We would expect to find that repeated interactions allow investment banks to control the demand in the primary market resulting in less uncertainty and a better price accuracy process. As we introduce a further premarket factor that accounts for the existence of a relationship between underwriters and regular investors we control for the presence of past relationships between these agents- as potential influences of the distance from the frontier - by using of the average number of interactions which occurred between the underwriter and institutional investors before the IPO.

\subsection{Measurement of Relationship Variables}

Previous literature dealing with the effects of interactions on the IPO results provided several relationship measures which were mainly used to investigate whether favouritism was practiced by lead managers by allocating shares to regular clients i.e. institutional investors. Pollock (2004) defined a Deal Network Embeddedness measure calculated using a Herfindahl index. Binay et al. (2007) proposed a measure of relationship participation that reflected the tendency of institutional investors to participate in an IPO linked to their involvement in past IPOs managed by the same lead underwriter. More recently Goyal and Tam (2013) developed a measure of long-term investing to examine whether long-term investors receive more IPO allocations than short-term investors. These scholars computed the strength of the relationship as the recurrence of the investor's presence in the underwriter's IPOs with values close or equal to one indicating a strong relationship between the investor and the underwriter.

Following an established empirical approach, we use the first reported holdings at the end of the offering quarter as a proxy for participation in the IPO (Reuter, 2006; Ritter \& Zhang, 2007; Goyal \& Tam, 2013; Field \& Lowry, 2009). In details we first identified for each IPO the name of the lead managers and the name of investors who declared holdings at the end of the offering quarter. Then we computed all the possible pairs of underwriters-funds for each IPO in the sample and searched for the recurrence of these pairs in different time spans: a quarter, a year, two and three years before the IPO (Note 13). Finally, we scaled each value by the number of different couples in the IPO to account for the relative effect of these relationships. Formally we have:

$$
\text { Relationship }_{k}=\frac{\sum D_{i j}}{N_{i j}}
$$

Where $k$ is the IPO of our sample $D_{i j}$ is the number of deals in the years before the IPO $k$ in which underwriter $j$ took part and the institutional investor i owned shares. $\mathrm{N}_{\mathrm{ij}}$ represents the number of different pairs of underwriter $\mathrm{j}$ and investor i present in the IPO $\mathrm{k}$ (Note 14).

Table 2 reports the distribution of the number of lead underwriters categorized from one to five during our sample period. Contrary to Jeon, Lee, Nasser and Via, (2015) and Hu and Ritter (2010) the results show that there has not been a trend toward a higher number of multiple lead underwriters per IPO in our sample. 
Table 2. Distribution of number of lead underwriters by Year and IPO

\begin{tabular}{|c|c|c|c|c|c|c|c|}
\hline \multirow[b]{2}{*}{ IPO Year } & \multicolumn{7}{|c|}{ Number of Lead Underwriters by Year and IPO } \\
\hline & 1 & 2 & 3 & 4 & 5 & $>5$ & Total \\
\hline 2000 & 139 & 12 & 5 & 0 & 0 & 0 & 156 \\
\hline 2001 & 29 & 11 & 0 & 0 & 0 & 0 & 40 \\
\hline 2002 & 31 & 10 & 0 & 0 & 0 & 0 & 41 \\
\hline 2003 & 18 & 6 & 1 & 0 & 0 & 0 & 25 \\
\hline 2004 & 49 & 43 & 6 & 3 & 0 & 0 & 101 \\
\hline 2005 & 80 & 35 & 5 & 2 & 1 & 0 & 123 \\
\hline 2006 & 75 & 36 & 8 & 1 & 0 & 0 & 120 \\
\hline 2007 & 79 & 33 & 11 & 6 & 0 & 0 & 129 \\
\hline 2008 & 10 & 6 & 5 & 0 & 0 & 0 & 21 \\
\hline 2009 & 11 & 13 & 7 & 4 & 2 & 2 & 39 \\
\hline 2010 & 27 & 24 & 16 & 5 & 9 & 4 & 85 \\
\hline 2011 & 27 & 17 & 11 & 6 & 11 & 4 & 76 \\
\hline 2012 & 21 & 19 & 16 & 11 & 10 & 7 & 84 \\
\hline 2013 & 33 & 35 & 24 & 13 & 8 & 11 & 124 \\
\hline 2014 & 42 & 35 & 34 & 7 & 4 & 12 & 134 \\
\hline 2015 & 19 & 28 & 25 & 9 & 1 & 7 & 89 \\
\hline 2016 & 4 & 9 & 11 & 4 & 3 & 5 & 36 \\
\hline Total & 694 & 372 & 185 & 71 & 49 & 52 & 1423 \\
\hline
\end{tabular}

\section{Empirical results}

\subsection{Summary statistics}

Table 3 presents summary statistics for the 1677 IPOs in our sample. The average offering price is US\$14.38 per share. The average value of total assets of the listing firms prior to the offer as a measure of the level of operations is US $\$ 1.55$ billion. The mean EBIT of IPO firms is US\$32 million and on average firms with negative EBIT constitute $40 \%$ of the sample. The leverage which is measured by the long-term debt scaled by the book value of assets shows a $26 \%$ mean value. In our sample firms go public on average 16 years after their foundation. The offer size variable indicates that on average firms have US\$95 million. On average underwriting fees are $\$ 11$ million. Figure 1 shows the dynamic of the fee across our sample period. In 2008 the number of firms that went public decreased; at the same time the compensation required by lead managers increased. Almost all the issues in the sample have a lock-up agreement in their prospectus.

The average rank of an underwriter is 8.2 out of a maximum attainable of 9; so, we can conclude that on average only highly ranked underwriters followed the issues in our sample. The average number of past relationships for the sample firms ranges from a minimum of 0.6 in the quarter before the issue to a maximum of 4.9 in the previous three years. The shares owned by insiders' amount to approximatively $60 \%$ which could be a positive signal of how confident the insiders are regarding the firm's prospects.

Table 3. Summary statistics

\begin{tabular}{|c|c|c|c|c|c|}
\hline & Mean & Median & Sd & Min & Max \\
\hline \multicolumn{6}{|c|}{ Panel A: pricing factors } \\
\hline Offer price (US\$) & 14.38 & 14 & 5.733 & 5 & 91 \\
\hline EBIT & 2.738 & 2.792 & 1.579 & -4.828 & 9.408 \\
\hline NEG_EBIT (0/1) & 0.441 & 0 & 0.497 & 0 & 1 \\
\hline FIRM_SIZE & 4.685 & 4.456 & 2.078 & -6.907 & 12.516 \\
\hline LEV & 0.266 & 0.093 & 0.436 & 0 & 8.448 \\
\hline \multicolumn{6}{|c|}{ Panel B: deliberate premarket factors } \\
\hline AGE (year) & 16.13 & 8 & 23.13 & 0 & 158 \\
\hline EQ_RET (\%) & 0.604 & 0.652 & 1.165 & -12.43 & 4.220 \\
\hline $\operatorname{LOCK}-\mathrm{UP}(0 / 1)$ & 0.919 & 1 & 0.273 & 0 & 1 \\
\hline FEE & 1.990 & 1.931 & 0.882 & -1.272 & 5.271 \\
\hline UW REP & 8.250 & 8.501 & 1.147 & 2.001 & 9.001 \\
\hline HOT_COLD & 14.62 & 12 & 11.49 & 0 & 63 \\
\hline OFFER_SIZE & 95.05 & 0.930 & 3253 & 0 & 124475 \\
\hline IPO_DEM (\%) & -0.013 & 0 & 0.127 & -0.500 & 0.667 \\
\hline $\mathrm{R} Q \mathrm{Q}$ & 0.657 & 0.430 & 0.794 & 0 & 11 \\
\hline $\mathrm{R} \_1 \mathrm{Y}$ & 2.336 & 1.769 & 2.325 & 0 & 19 \\
\hline$R \_2 Y$ & 3.834 & 2.779 & 3.895 & 0 & 36 \\
\hline R_3Y & 4.947 & 3.630 & 4.998 & 0 & 57 \\
\hline
\end{tabular}




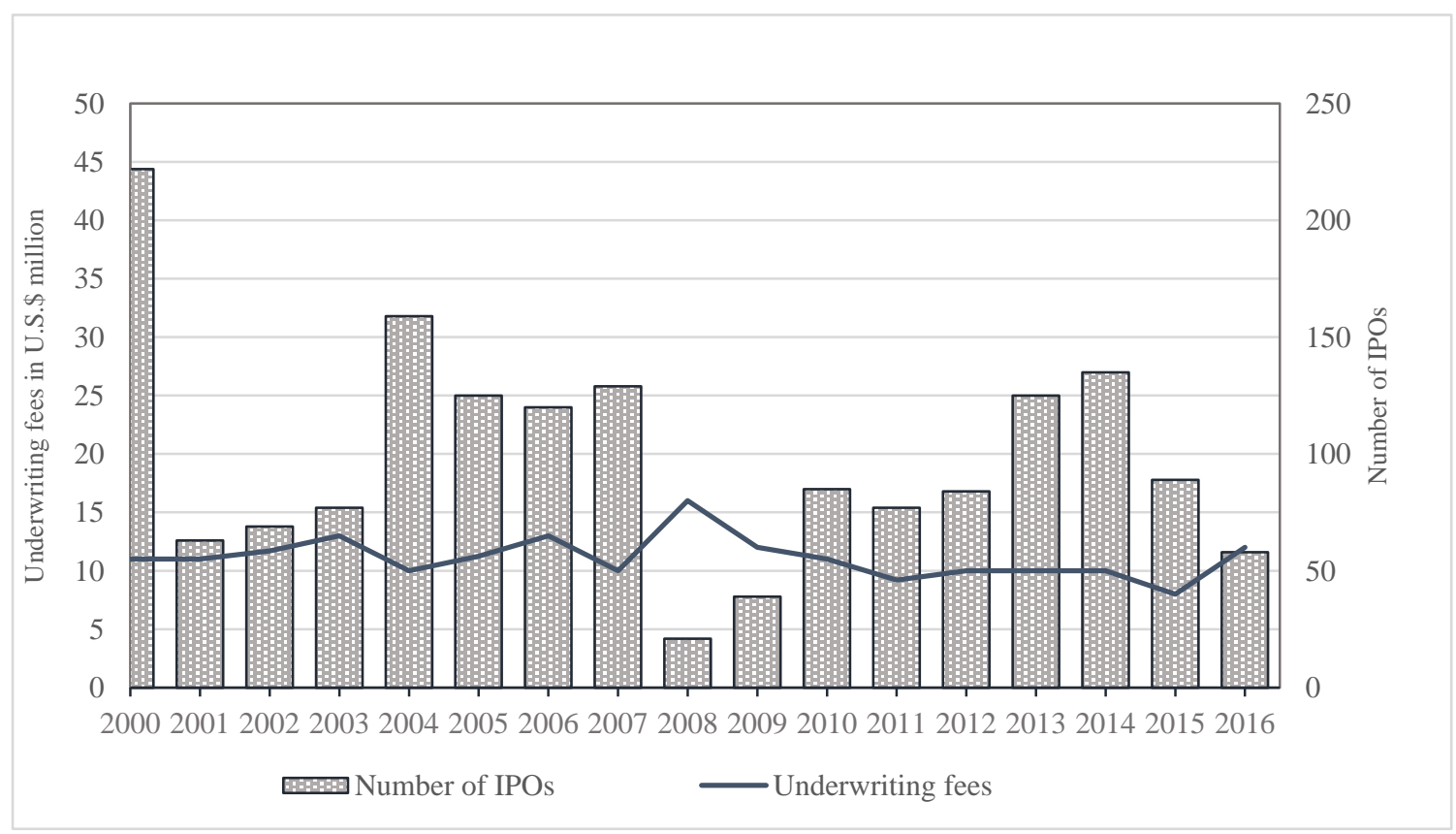

Figure 1. Underwriting fee and numbers of IPOs in our sample period

\subsection{Findings}

Table 4 presents the estimates of the Stochastic Frontier model. The output used in the stochastic frontier model is the natural logarithm of the offer price. The inputs or pricing factors $\mathrm{X}$ and the deliberate premarket factors $\mathrm{Z}$ used to model the variance of the non-idiosyncratic error component are those already discussed in Section 3.3.

Table 4. Stochastic Frontier Approach estimates

\begin{tabular}{lllll}
\hline & $(1)$ & $(2)$ & $(3)$ & $(4)$ \\
\hline \multirow{2}{*}{ EBIT } & & & & 0.0145 \\
& 0.0142 & 0.0133 & 0.0136 & $(1.42)$ \\
NEG_EBIT & $(1.42)$ & $(1.34)$ & $(1.37)$ & -0.0121 \\
FIRM_SIZE & -0.00834 & -0.00505 & -0.00443 & $(-0.38)$ \\
& $(-0.26)$ & $(-0.16)$ & $(-0.14)$ & $0.0373^{* *}$ \\
LEV & $0.0392^{* *}$ & $0.0406 * *$ & $0.0404 * *$ & $(2.96)$ \\
& $(3.06)$ & $(3.26)$ & $(3.26)$ & $-0.0349 * * *$ \\
OIL_GAS & $-0.0356^{* * *}$ & $-0.0353^{* * *}$ & $-0.0353^{* * *}$ & $(-4.40)$ \\
& $(-4.53)$ & $(-4.51)$ & $(-4.51)$ & -0.0423 \\
CHEMICAL & -0.0416 & -0.0392 & -0.0390 & $(-0.81)$ \\
MFG & $(-0.80)$ & $(-0.76)$ & $(-0.76)$ & $-0.150^{* * *}$ \\
& $-0.154 * * *$ & $-0.155 * * *$ & $-0.154 * * *$ & $(-3.29)$ \\
COMPUTERS & $(-3.42)$ & $(-3.50)$ & $(-3.49)$ & 0.0425 \\
ELECT_EQUIP & 0.0450 & 0.0421 & 0.0428 & $(0.50)$ \\
TRANS & $(0.53)$ & $(0.50)$ & $(0.51)$ & -0.0270 \\
SCIENT_INSTR & -0.0275 & -0.0296 & -0.0302 & $(-0.75)$ \\
COMM & $(-0.77)$ & $(-0.83)$ & $(-0.85)$ & -0.0787 \\
UTILITIES & $-0.0830 *$ & $-0.0854 *$ & $-0.0858^{*}$ & $(-1.63)$ \\
& $(-1.75)$ & $(-1.81)$ & $(-1.82)$ & 0.0900 \\
& 0.0860 & 0.0816 & 0.0809 & $(1.20)$ \\
& $(1.15)$ & $(1.11)$ & $(1.11)$ & -0.0763 \\
& -0.0790 & -0.0830 & -0.0850 & $(-1.30)$ \\
& $(-1.36)$ & $(-1.45)$ & $(-1.49)$ & -0.0503 \\
& -0.0539 & -0.0567 & -0.0574 & $(-0.70)$ \\
& $(-0.75)$ & $(-0.80)$ & $(-0.81)$ & 0.0232 \\
& 0.0316 & 0.0299 & 0.0316 & $(0.17)$
\end{tabular}




\begin{tabular}{|c|c|c|c|c|}
\hline RETAIL & $\begin{array}{l}0.00440 \\
(0.08)\end{array}$ & $\begin{array}{l}0.00319 \\
(0.06)\end{array}$ & $\begin{array}{l}0.00287 \\
(0.05)\end{array}$ & $\begin{array}{l}0.0128 \\
(0.22)\end{array}$ \\
\hline \multirow[t]{2}{*}{ FINANCIAL } & -0.00543 & -0.0000944 & -0.000269 & -0.00652 \\
\hline & $(-0.11)$ & $(-0.00)$ & $(-0.01)$ & $(-0.13)$ \\
\hline \multirow[t]{2}{*}{ HEALTH } & 0.0907 & 0.0887 & 0.0861 & 0.0943 \\
\hline & $(1.41)$ & (1.39) & $(1.35)$ & $(1.45)$ \\
\hline \multirow{2}{*}{ _cons } & $2.604 * * *$ & $2.608 * * *$ & $2.610 * * *$ & $2.602 * * *$ \\
\hline & $(40.97)$ & $(41.25)$ & $(41.47)$ & $(39.47)$ \\
\hline \multicolumn{5}{|l|}{$\ln \operatorname{sig} 2 \mathrm{v}$} \\
\hline _cons & $\begin{array}{l}-3.403 * * * \\
(-15.98)\end{array}$ & $\begin{array}{l}-3.454 * * * \\
(-18.61)\end{array}$ & $\begin{array}{l}-3.462 * * * \\
(-18.91)\end{array}$ & $\begin{array}{l}-3.325 * * * \\
(-15.85)\end{array}$ \\
\hline \multicolumn{5}{|l|}{$\ln \operatorname{sig} 2 \mathrm{u}$} \\
\hline \multirow[t]{2}{*}{ AGE } & 0.0653 & 0.0294 & 0.0259 & 0.107 \\
\hline & $(0.43)$ & $(0.25)$ & $(0.23)$ & $(0.55)$ \\
\hline \multirow[t]{2}{*}{ EQ_RET } & $-0.199 * *$ & $-0.196 * *$ & $-0.194 * *$ & $-0.199 *$ \\
\hline & $(-2.02)$ & $(-2.03)$ & $(-2.02)$ & $(-1.93)$ \\
\hline \multirow[t]{2}{*}{ LOCK-UP } & 0.573 & 0.534 & 0.517 & 0.513 \\
\hline & $(0.64)$ & $(0.63)$ & $(0.61)$ & $(0.53)$ \\
\hline \multirow[t]{2}{*}{ FEE } & $-1.517 * * *$ & $-1.448 * * *$ & $-1.453 * * *$ & $-1.626 * * *$ \\
\hline & $(-4.51)$ & $(-5.84)$ & $(-5.96)$ & $(-3.95)$ \\
\hline \multirow[t]{2}{*}{ UW_REP } & 0.102 & 0.0915 & 0.103 & 0.0587 \\
\hline & (1.10) & (1.01) & (1.13) & $(0.61)$ \\
\hline \multirow[t]{2}{*}{ HOT_COLD } & -0.00468 & -0.00476 & -0.00467 & -0.00460 \\
\hline & $(-0.52)$ & $(-0.54)$ & $(-0.54)$ & $(-0.48)$ \\
\hline \multirow[t]{2}{*}{ OFFER_SIZE } & $-0.408 * * *$ & $-0.417 * * *$ & $-0.418 * * *$ & $-0.382 * * *$ \\
\hline & $(-3.90)$ & $(-4.24)$ & $(-4.28)$ & $(-3.54)$ \\
\hline \multirow[t]{2}{*}{ IPO_DEM } & $-1.333^{*}$ & $-1.353^{*}$ & $-1.335^{*}$ & $-1.366^{*}$ \\
\hline & $(-1.82)$ & $(-1.92)$ & $(-1.90)$ & $(-1.76)$ \\
\hline \multirow[t]{2}{*}{ R_1Y } & $-0.102^{*}$ & & & \\
\hline & $(-1.94)$ & & & \\
\hline R_2Y & & $-0.0482 *$ & & \\
\hline \multirow[t]{2}{*}{ R_3Y } & & $(-1.14)$ & $-0.0429^{*}$ & \\
\hline & & & $(-1.92)$ & \\
\hline \multirow[t]{2}{*}{ R_Q } & & & & -0.161 \\
\hline & & & & $(-0.84)$ \\
\hline \multirow[t]{2}{*}{ _cons } & -0.873 & -0.762 & -0.789 & -0.619 \\
\hline & $(-0.72)$ & $(-0.65)$ & $(-0.68)$ & $(-0.48)$ \\
\hline
\end{tabular}

Note. All four models use the same pricing factors. Model 1 estimates the fair offer price as a function of ex ante uncertainty surrounding firm value; we add deliberate premarket factors that explain variations from the maximum achievable offer price and also the RELATIONSHIP1Y variable that accounts for the average number of relationships between underwriter and investors in the year before the IPO. Model 2 replaces RELATIONSHIP1Y with average number of relationships between underwriter and investors in the two years before the IPO (RELATIONSHIP2Y). Model 3 replaces RELATIONSHIP2Y with average number of relationships between underwriter and investors in the three years before the IPO (RELATIONSHIP3Y). Model 4 replaces RELATIONSHIP3Y with average number of relationships between underwriter and investors in the quarter before the IPO (RELATIONSHIP). $* * *, * *$ and $*$ denotes the statistical significance at the $1 \%, 5 \%$ and $10 \%$ level respectively. T statistics are reported in the parentheses.

As for the control variables estimated results show that EBIT is strongly and positively associated with the offer price of the issuing firm while the leverage has a strong negative association. Basically, these findings show that the offer price should be higher when the firm has stronger earning power and lower when it has greater risk and distress costs (Teoh et al., 1998; Chen et al., 2002). In contrast with Chen et al. (2002) but in line with Hunt-McCool et al. (1996) and Peng and Wang (2007) we found a positive impact of the asset book value on the IPO offer price. Contrary to Koop and $\mathrm{Li}$ (2001) however we found that firms belonging to industries with great growth potential such as chemical products and scientific instruments are undervalued.

When the characteristics of the deal are considered we find that the higher the equity retained by the insiders the smaller the distance from the maximum achievable offer price. This result suggests that underwriters might take into account equity retention when pricing the IPO because the greater the retention the lower the probability of required aftermarket price support and consequently the lower the variance of the inefficient error component. Also, we find evidence that the proportion of stocks owned by insiders has a positive signalling effect on the IPO 
firm value whereas the offer size is negatively related to the offer price as found by Peng and Wang (2007) and Reber and Vencappa (2016). Moreover, empirical findings support the idea that smaller issues are perceived as more speculative as the higher size of the offer is associated with a lower distance from the frontier (Hunt-McCool et al., 1996; Tinic, 1988) and that the underwriter reputation is not a critical variable in explaining the offer pricing. This last result is in line with Reber and Vencappa (2016) who conclude that underwriters' reputation does not affect the level of deliberate premarket underpricing and suggest that it is the amount of money spent on underwriting rather than the choice of a particular underwriter which is important in the primary market pricing (Koop \& $\mathrm{Li}, 2001$ ). Finally, we found a significant influence of the market conditions on pricing: specifically, we found that the higher the number of IPOs occurring in the month before the issue the lower the distance from the frontier. In other terms if the market is 'hot' there is no need for the investment bank to apply an intentional discount to guarantee the complete subscription of the offer.

As far as the core variables are concerned, $\mathrm{R} \_1 \mathrm{Y}$ in model 1 represents our main variable as it informs about the interactions that occurred between the underwriter and institutional investors in the year before the IPO. The coefficient of this variable is negative and significant: this means that IPOs characterized by a coalition of dealers one year before the IPO tend to experience a lower variance on the asymmetric error term. Accordingly, the distance from the frontier is lower that is the offer price is closer to its intrinsic value as expected in Hyp (1). The core of this finding is that relationships matter and even more importantly relationships might be a benefit for issuers as the price is closer to the optimal one. Such a result is consistent with Benveniste and Spindt (1989) in that bookbuilding is a way of collecting relevant information. However, despite our model reveals that the price is set closer to the fair offer price previous theories of partial adjustment suggest that it is not set equal to the true value of the issuing firm. Indeed Hanley (1993) suggests that the offer price is raised less that it could be in order to guarantee a premium for the investors for revealing their indication of interest to underwriters.

Models 2 and 3 replace the variable relative to the relationships in the year before the IPO with the two- and three- year specification which is the average number of relationships that occurred in the two and three years prior the IPO. A negative impact on the distance from the frontier continues to be observed. Therefore, Hyp (1) is confirmed even in a larger time interval as a longer horizon does not change the positive effect of the relationships on the level of price accuracy. Model 4 replaces the yearly relationship variable with a measure that refers to the quarter before the offering. This change is motivated by the need to test the role of stricter relationships occurred just before the deal. Estimated results show that this variable is not significant and support the intuition of Hyp (2) that is relationships occurred in the quarter before the IPO - i.e. arm's length ties - are not able to influence the IPO price setting mechanism significantly. By contrast only when the collaboration is ongoing and repeated over time a stock of trust is created large enough to generate embedded ties which in turn favour economic action resource pooling and cooperation (Daily et al., 2003; Granovetter, 2005). These results suggest that repeated interactions are able to generate more favourable information for the IPO firms and that underwriters use this information to more efficiently price the IPO. This allows underwriters to preserve their reputation and to generate future business.

\section{Discussion}

In this work we investigate the role of interactions between lead managers and institutional investors in the IPO primary market pricing. Building on the roles traditionally assigned to investment banks we test hypotheses about the role played by the bank's relationships with regular investors in IPO pricing by exploiting the role played by different periods of time. We fill a gap in the extant literature by proposing a model of primary market pricing where a measure of the incomplete adjustment of the offer price to its maximum achievable is related to the intensity of interactions between IPO players in the years before the IPO. To empirically reveal the extent of dealers' coalition we made use of the average number of relationships between regular investors and lead managers in different periods before the IPO (one quarter one year two years and three years). We checked our intuition within a stochastic frontier approach in order to investigate the effects of relationships between these players on pricing and more specifically on the variance of the asymmetric error component.

Our main finding is that IPOs with a stronger bank-investor relationship are set with offer prices that are closer to the intrinsic value. Moreover, by controlling for the demand revealed during bookbuilding the analysis shows that the existence of repeated interactions allows the banks to have a control on the demand in the primary market which reduces uncertainty and leads to a higher price efficiency to the benefit of issuers.

Our paper provides additional contributes to the debate on why bookbuilding is still the most common and dominant going-public method (Lowry et al., 2017) despite its higher costs. We shed some light on the pricing dynamics involving the primary market by proving evidence the possible positive effects of repeated interactions 
on IPO offer price. Building a clientele of regular investors allows the investment bank to lessen the dilemma of pricing the IPOs and to balance competing interests in strategic information. According to our results banks that engage in a repeated "game" with a coalition of investors can acquire information that is useful for setting the offer price during bookbuilding. At the same time banks may compensate investors for the information they generate by favouring them with the participation and allocation of future IPOs and benefit issuers in terms of a smaller gap between the actual and the maximum potential offer price.

To sum up, although our results are not directly comparable with previous studies - which mainly focus on allocations of underpriced shares - our findings provide a contribution to the growing literature on the role of coalitions in that, following the view of Ritter and Welch (2002), "the solution to the underpricing puzzle has to lie in focusing on the setting of the offer price".

\section{References}

Aggarwal, R. (2003). Allocation of initial public offerings and flipping activity. Journal of Financial Economics, 68(1), 111-135. https://doi.org/10.1016/S0304-405X(02)00250-7

Aigner, D., Lovell, C. K., \& Schmidt, P. (1977). Formulation and estimation of stochastic frontier production function models. Journal of Econometrics, 6(1), 21-37. https://doi.org/10.1016/0304-4076(77)90052-5

Arthurs, J. D., Hoskisson, R. E., Busenitz, L. W., \& Johnson, R. A. (2008). Managerial agents watching other agents: Multiple agency conflicts regarding underpricing in IPO firms. Academy of Management Journal, 51(2), 277-294. https://doi.org/10.5465/amj.2008.31767256

Baker, W. E. (1990). Market networks and corporate behaviour. American Journal of Sociology, 96(3), 589-625. https://doi.org/10.1086/229573

Baron, D. P. (1982). A model of the demand for investment banking advising and distribution services for new issues. The Journal of Finance, 37(4), 955-976. https://doi.org/10.1111/j.1540-6261.1982.tb03591.x

Beatty, R. P., \& Ritter, J. R. (1986). Investment banking, reputation, and the underpricing of initial public offerings. Journal of Financial Economics, 15(1-2), 213-232. https://doi.org/10.1016/0304-405X(86)90055-3

Benveniste, L. M., \& Spindt, P. A. (1989). How investment bankers determine the offer price and allocation of new issues. Journal of Financial Economics, 24(2), 343-361. https://doi.org/10.1016/0304-405X(89)90051-2

Benveniste, L. M., \& Wilhelm, W. J. (1990). A comparative analysis of IPO proceeds under alternative regulatory environments. Journal of Financial Economics, 28(1-2), 173-207. https://doi.org/10.1016/0304-405X(90)90052-2

Benveniste, L. M., Busaba, W. Y., \& Wilhelm Jr, W. J. (2002). Information externalities and the role of underwriters in primary equity markets. Journal of Financial Intermediation, 11(1), 61-86. https://doi.org/10.1006/jfin.2000.0310

Benveniste, L. M., Busaba, W. Y., \& Wilhelm, W. J. (1996). Price stabilization as a bonding mechanism in new equity issues. Journal of Financial Economics, 42(2), 223-255. https://doi.org/10.1016/0304-405X(96)00880-X

Binay, M. M., Gatchev, V. A., \& Pirinsky, C. A. (2007). The role of underwriter-investor relationships in the IPO process. Journal of Financial and Quantitative Analysis, 42(03), 785-809. https://doi.org/10.1017/S002210900000418X

Bradley, D. J., \& Jordan, B. D. (2002). Partial adjustment to public information and IPO underpricing. Journal of Financial and Quantitative Analysis, 37(04), 595-616. https://doi.org/10.2307/3595013

Bradley, D. J., Jordan, B. D., Yi, H. C., \& Roten, I. C. (2001). Venture capital and IPO lockup expiration: An empirical analysis. Journal of Financial Research, 24(4), 465-493.

https://doi.org/10.1111/j.1475-6803.2001.tb00826.x

Brav, A., \& Gompers, P. A. (2003). The role of lockups in initial public offerings. The Review of Financial Studies, 16(1), 1-29. https://doi.org/10.1093/rfs/16.1.0001

Busaba, W. Y., Benveniste, L. M., \& Guo, R. J. (2001). The option to withdraw IPOs during the premarket: empirical analysis. Journal of Financial Economics, 60(1), 73-102.

https://doi.org/10.1016/S0304-405X(01)00040-X 
Busaba, W. Y., Liu, Z., \& Restrepo, F. (2019). Do underwriters price-up IPOs to prevent withdrawal? Journal of Financial and Quantitative Analysis, 55(6), 1-64. https://doi.org/10.1017/S0022109019000553

Calomiris, C. W., \& Pornrojnangkool, T. (2009). Relationship banking and the pricing of financial services. Journal of Financial Services Research, 35(3), 189-224. https://doi.org/10.1007/s10693-009-0058-7

Carter, R. B., Dark, F. H., \& Singh, A. K. (1998). Underwriter reputation, initial returns, and the long-run performance of IPO stocks. The Journal of Finance, 53(1), 285-311. https://doi.org/10.1111/0022-1082.104624

Carter, R., \& Manaster, S. (1990). Initial public offerings and underwriter reputation. The Journal of Finance, 45(4), 1045-1067. https://doi.org/10.1111/j.1540-6261.1990.tb02426.x

Chalk, A. J., \& Peavy, J. W. (1987). Initial public offerings: daily returns, offering types and the price effect. Financial Analysts Journal, 43(5), 65-69. https://doi.org/10.2469/faj.v43.n5.65

Chan, Y. C., Wu, C., \& Kwok, C. C. (2007). Valuation of global IPOs: a stochastic frontier approach. Review of Quantitative Finance and Accounting, 29(3), 267-284. https://doi.org/10.1007/s11156-007-0035-x

Chen, A., Hung, C. C., \& Wu, C. S. (2002). The underpricing and excess returns of initial public offerings in Taiwan based on noisy trading: a stochastic frontier model. Review of Quantitative Finance and Accounting, 18(2), 139-159. https://doi.org/10.1023/A:1014565018160

Chowdhry, B., \& Nanda, V. (1996). Stabilization, syndication, and pricing of IPOs. Journal of Financial and Quantitative Analysis, 31(1), 25-42. https://doi.org/10.2307/2331385

Chuluun T. (2015). The role of underwriter peer networks in IPOs, Journal of Banking \& Finance, 51, 62-78. https://doi.org/10.1016/j.jbankfin.2014.11.001

Daily, C. M., Certo, S. T., Dalton, D. R., \& Roengpitya, R. (2003). IPO underpricing: A meta-analysis and research synthesis. Entrepreneurship Theory and Practice, 27(3), 271-295. https://doi.org/10.1111/1540-8520.t01-1-00004

Davis, R. L., Jurich, S. N., Roseman, B. S., \& Watson, E. D. (2018). Short-Sale Restrictions and Price Clustering: Evidence from SEC Rule 201. Journal of Financial Services Research, 54(3), 345-367. https://doi.org/10.1007/s10693-017-0272-7

DeYoung, R., \& Li, L. (2019). Publicly Traded Versus Privately Held Commercial Banks: Sensitivity to Growth Opportunities. Journal of Financial Services Research, 1-33. https://doi.org/10.1007/s10693-019-00310-y

Engelen, P., \& van Essen, M. (2010). Underpricing of IPOs: Firm-, issue- and country-specific characteristics, Journal of Banking and Finance, 34, 1958-1969. https://doi.org/10.1016/j.jbankfin.2010.01.002

Field, L. C., \& Hanka, G. (2001). The expiration of IPO share lockups. The Journal of Finance, 56(2), 471-500. https://doi.org/10.1111/0022-1082.00334

Field, L. C., \& Lowry, M. (2009). Institutional versus individual investment in IPOs: The importance of firm fundamentals. Journal of Financial and Quantitative Analysis, 44(3), 489-516. https://doi.org/10.1017/S0022109009990032

Francis, B. B., \& Hasan, I. (2001). The underpricing of venture and nonventure capital IPOs: An empirical investigation. Journal of Financial Services Research, 19(2), 99-113. https://doi.org/10.1023/A:1011134715911

Geranio, M., Mazzoli, C., \& Palmucci, F. (2017). The effects of affiliations on the initial public offering pricing. International Review of Economics and Finance, 51, 295-313. https://doi.org/10.1016/j.iref.2017.06.002

Goldstein, M. A., Irvine, P., \& Puckett, A. (2011). Purchasing IPOs with commissions. Journal of Financial and Quantitative Analysis, 46(5), 1193-1225. https://doi.org/10.1017/S0022109011000317

Gondat-Larralde, C., \& James, K. R. (2008). IPO pricing and share allocation: The importance of being ignorant. The Journal of Finance, 63(1), 449-478. https://doi.org/10.1111/j.1540-6261.2008.01321.x

Goyal, V., \& Tam, H. K. (2013). Investor characteristics, relationships, and IPO allocations. Working Paper. https://doi.org/10.2139/ssrn.1595865

Granovetter, M. (2005). The impact of social structure on economic outcomes. The Journal of Economic Perspectives, 19(1), 33-50. https://doi.org/10.1257/0895330053147958 
Gulati, R., \& Higgins, M. C. (2003). Which ties matter when? the contingent effects of interorganizational partnerships on IPO success. Strategic Management Journal, 24(2), 127-144. https://doi.org/10.1002/smj.287

Habib, M. A., \& Ljungqvist, A. P. (2001). Underpricing and entrepreneurial wealth losses in IPOs: Theory and evidence. The Review of Financial Studies, 14(2), 433-458. https://doi.org/10.1093/rfs/14.2.433

Hanley, K. W. (1993). The underpricing of initial public offerings and the partial adjustment phenomenon. Journal of Financial Economics, 34(2), 231-250. https://doi.org/10.1016/0304-405X(93)90019-8

Hanley, K. W. (2017). The economics of primary markets. Working Paper. https://doi.org/10.2139/ssrn.3046256

Heaton, J. B. (2002). Managerial optimism and corporate finance. Financial Management, 31(2), 33-45. https://doi.org/10.2307/3666221

Hu, W., \& Ritter, J. (2007). Multiple Bookrunners in IPOs. University of Florida, Working Paper. https://doi.org/10.2139/ssrn. 972628

Hughes, P. J. (1986). Signalling by direct disclosure under asymmetric information. Journal of Accounting and Economics, 8(2), 119-142. https://doi.org/10.1016/0165-4101(86)90014-5

Hunt-McCool, J., Koh, S. C., \& Francis, B. B. (1996). Testing for deliberate underpricing in the IPO premarket: A stochastic frontier approach. Review of Financial Studies, 9(4), 1251-1269. https://doi.org/10.1016/0165-4101(86)90014-5

Ibbotson, R. G., \& Ritter, J. R. (1995). Initial public offerings. Handbooks In Operations Research And Management Science, 9(30), 993-1016. https://doi.org/10.1016/S0927-0507(05)80074-X

Ibbotson, R. G., Sindelar, J. L., \& Ritter, J. R. (1988). Initial public offerings. Journal of Applied Corporate Finance, 1(2), 37-45. https://doi.org/10.1111/j.1745-6622.1988.tb00164.x

Jain, B. A., \& Kini, O. (1994). The post-issue operating performance of IPO firms. The Journal of Finance, 49(5), 1699-1726. https://doi.org/10.1111/j.1540-6261.1994.tb04778.x

Jenkinson, T., Jones, H., \& Suntheim, F. (2018). Quid pro quo? What factors influence IPO allocations to investors? The Journal of Finance, 73(5), 2303-2341. https://doi.org/10.1111/jofi.12703

Jeon, J. Q., Lee, C., Nasser, T., \& Via, M. T. (2015). Multiple lead underwriter IPOs and firm visibility. Journal of Corporate Finance, 32, 128-149. https://doi.org/10.1016/j.jcorpfin.2015.04.007

Johnston, J., Madura, J., \& Harper, J. T. (2005). Interaction between short selling and potential insider selling in the IPO aftermarket. Journal of Financial Services Research, 27(3), 283-302. https://doi.org/10.1016/0304-4076(82)90004-5

Jondrow, J., Lovell, C. K., Materov, I. S., \& Schmidt, P. (1982). On the estimation of technical inefficiency in the stochastic frontier production function model. Journal of Econometrics, 19(2-3), 233-238. https://doi.org/10.1016/0304-4076(82)90004-5

Kim, M., \& Ritter, J. R. (1999). Valuing IPOs. Journal of Financial Economics, 53(3), 409-437. https://doi.org/10.1016/S0304-405X(99)00027-6

Koop, G., \& Li, K. (2001). The valuation of IPO and SEO firms. Journal of Empirical Finance, 8(4), 375-401. https://doi.org/10.1016/S0927-5398(01)00033-0

Krinsky, I., \& Rotenberg, W. (1989). Signalling and the valuation of unseasoned new issues revisited. Journal of Financial and Quantitative Analysis, 24(2), 257-266. https://doi.org/10.2307/2330775

Kumbhakar, S. C., \& Lovell, C. K. (2003). Stochastic Frontier Analysis. Cambridge university press.

Liu, X., \& Ritter, J. R. (2010). The economic consequences of IPO spinning. The Review of Financial Studies, 23(5), 2024-2059. https://doi.org/10.1093/rfs/hhq002

Ljungqvist, A. P., \& Wilhelm, W. J. (2002). IPO allocations: Discriminatory or discretionary? Journal of Financial Economics, 65(2), 167-201. https://doi.org/10.1016/S0304-405X(02)00138

Loughran, T., \& Ritter, J. (2004). Why has IPO underpricing changed over time? Financial Management, 33, 5-37. http://dx.doi.org/10.2139/ssrn.331780

Lowry, M., \& Murphy, K. J. (2007). Executive stock options and IPO underpricing. Journal of Financial Economics, 85(1), 39-65. https://doi.org/10.1016/j.jfineco.2006.05.006

Lowry, M., \& Shu, S. (2002). Litigation risk and IPO underpricing. Journal of Financial Economics, 65(3), 
309-335. https://doi.org/10.1016/S0304-405X(02)00144-7

Lowry, M., Michaely, R., \& Volkova, E., et al. (2017). Initial public offerings: A synthesis of the literature and directions for future research. Foundations and Trends in Finance, 11(3-4), 154-320. http://dx.doi.org/10.2139/ssrn.2912354

Luo, C., \& Ouyang, Z. (2014). Estimating IPO pricing efficiency by Bayesian stochastic frontier analysis: The chinext market case. Economic Modelling, 40, 152-157. https://doi.org/10.1016/j.econmod.2014.03.030

Marchand, J., \& Roufagalas, J. (1996). Search and uncertainty: Determinants of the degree of underpricing of initial public offerings. Journal of Economics and Finance, 20(1), 47. https://doi.org/10.1007/BF02920498

Meng, J. G., Zhang, W., \& Zou, G. (2016). Deliberate IPO underpricing or market misvaluation? new evidence from china. China Accounting and Finance Review, 18(4), 1-22. https://doi.org/10.7603/s40570-016-0013-6

Myers, S. C., \& Majluf, N. S. (1984). Corporate financing and investment decisions when firms have information that investors do not have. Journal of Financial Economics, 13(2), 187-221. https://doi.org/10.1016/0304-405X(84)90023-0

Neupane S., \& Poshakwale, S. S. (2012). Transparency in IPO mechanism: Retail investors' participation, IPO pricing and returns. Journal of Banking and Finance, 36(7), 2064-2076. https://doi.org/10.1016/j.jbankfin.2012.03.010

Peng, Y., \& Wang, K. (2007). IPO underpricing and flotation methods in Taiwan-a stochastic frontier approach. Applied Economics, 39(21), 2785-2796. https://doi.org/10.1080/00036840600749417

Pollock, T. G. (2004). The benefits and costs of underwriters' social capital in the us initial public offerings market. Strategic Organization, 2(4), 357-388. https://doi.org/10.1177/1476127004047618

Reber, B., \& Vencappa, D. (2016). Deliberate premarket underpricing and aftermarket mispricing: New insights on IPO pricing. International Review of Financial Analysis, 44, 18-33. https://doi.org/10.1016/j.irfa.2015.11.007

Reuter, J. (2006). Are IPO allocations for sale? evidence from mutual funds. The Journal of Finance, 61(5), 2289-2324. https://doi.org/10.1111/j.1540-6261.2006.01058.x

Ritter, J. R. (1987). The costs of going public. Journal of Financial Economics, 19(2), 269-281. https://doi.org/10.1016/0304-405X(87)90005-5

Ritter, J. R. (1991). The long-run performance of initial public offerings. The Journal of Finance, 46(1), 3-27. https://doi.org/10.1111/j.1540-6261.1991.tb03743.x

Ritter, J. R. (2011). Equilibrium in the initial public offerings market. Annual Review of Financial Economics 3(1), 347-374. https://doi.org/10.1146/annurev-financial-102710-144845

Ritter, J. R., \& Welch, I. (2002). A review of IPO activity, pricing, and allocations. The Journal of Finance, 57(4), 1795-1828. https://doi.org/10.1111/1540-6261.00478

Ritter, J. R., \& Zhang, D. (2007). Affiliated mutual funds and the allocation of initial public offerings. Journal of Financial Economics, 86(2), 337-368. https://doi.org/10.1016/j.jfineco.2006.08.005

Rock, K. (1986). Why new issues are underpriced. Journal of Financial Economics, 15(1-2), 187-212. https://doi.org/10.1016/0304-405X(86)90054-1

Roosenboom, P. (2012). Valuing and pricing IPOs, Journal of Banking and Finance, 36(6), 1653-1664. https://doi.org/10.1016/j.jbankfin.2012.01.009

See, K. F., \& Rashid, A. A. (2011). Determinants of non-disclosure of intellectual capital information in Malaysian IPO prospectuses. International Journal of Economics and Finance, 3(5), 178. https://doi.org/10.5539/ijef.v3n5p178

Sherman, A. E., \& Titman, S. (2002). Building the IPO order book: underpricing and participation limits with costly information. Journal of Financial Economics, 65(1), 3-29. https://doi.org/10.1016/S0304-405X(02)00133-2

Spatt, C., \& Srivastava, S. (1991). Preplay communication, participation restrictions, and efficiency in initial public offerings. The Review of Financial Studies, 4(4), 709-726. https://doi.org/10.1111/0022-1082.00079

Teoh, S. H., Welch, I., \& Wong, T. J. (1998). Earnings management and the long-run market performance of initial public offerings. The Journal of Finance, 53(6), 1935-1974. 
Tinic, S. M. (1988). Anatomy of initial public offerings of common stock. The Journal of Finance, 43(4), 789-822. https://doi.org/10.1111/j.1540-6261.1988.tb02606.x

Uzzi, B. (1999). Embeddedness in the making of financial capital: How social relations and networks benefit firms seeking financing. American Sociological Review, 481-505. https://doi.org/10.2307/2657252

Uzzi, B., \& Gillespie, J. J. (1999). Corporate social capital and the cost of financial capital: An embeddedness approach, Corporate Social Capital and Liability, 23, 446-459. https://doi.org/10.1007/978-1-4615-5027-3_25

Wilhelm, W. J. (2005). Bookbuilding, auctions, and the future of the IPO process. Journal of Applied Corporate Finance, 17(1), 55-66. https://doi.org/10.1111/j.1745-6622.2005.024_1.x

Wu, C., \& Kwok, C. C. (2003). The pricing of global and domestic initial public offerings by us companies. Journal of Banking and Finance, 27(6), 1167-1184. https://doi.org/10.1016/S0378-4266(02)00248-0

Yan, X. S., \& Hao, Q. (2012). The performance of investment bank-affiliated mutual funds: Conflicts of interest or informational advantage? Journal of Financial and Quantitative Analysis, 47(3), 537-565. https://doi.org/10.1017/S0022109012000178

\section{Notes}

Note 1. Investment banks receive revenues from the commissions paid by the issuers (the gross spreads) as a percentage of the capital raised. In addition, they can benefit from underpriced offerings, if they have discretion in allocating shares, to rent-seeking investors, who repay part of their trading profits with commissions in excess of direct execution costs. Investment banks and mutual fund families can also use underpriced IPOs to boost the performance of particular funds under their management (Ritter \& Zhang, 2007; Ritter, 2011; Yan \& Hao, 2012).

Note 2. On the empirical side, no conclusive findings regarding the role of repeated interactions on IPO primary market pricing have been provided. Existing research is mostly focused on the amount of underpriced shares that are allocated to institutional investors. However, data on actual IPO allocations are rarely disclosed by banks (Binay et al., 2007 and Hanley, 2017) and proxies of actual data have been used (Reuter, 2006; Ritter and Zhang, 2007; Goyal and Tam, 2013 and Field and Lowry, 2009). Moreover, the literature on the effect of the underwriters- investors' relationships on IPO primary market pricing hardly informs about the effect that repeated interactions produce along the preparation of an IPO in the primary market (Geranio, Mazzoli \& Palmucci, 2017).

Note 3. Generally, if information production is costly, underwriters need to decide how much information production to induce, resulting in a trade-off between the (issuer-specific) benefit of greater pricing accuracy and the cost of more information production (Sherman \& Titman, 2002).

Note 4. If there were no systematic underpricing, actual prices would fall below the frontier due to the presence of random factors, captured by idiosyncratic error term. The non-idiosyncratic disturbance error component represents deliberate underpricing.

Note 5. Stocks with a price below $\$ 5.00$ per share are subject to the provisions of the Securities Enforcement Remedies and Penny Stock Reform Act of 1990, aimed at reducing fraud and abuse in the penny stock market (Ritter, 1991).

Note 6. The sample was then reduced to 2,219 IPOs.

Note 7. Some information about issuing firm characteristics is also included in the TOD. Because of the absence of some relevant financial items and for easier comparison, we prefer to use Compustat as the single source of financial statement information.

Note 8. To account for technical inefficiency, $u_{i}$ can be assumed to follow either half normal, truncated normal, exponential, or two-parameter gamma and represents the independently distributed non-negative random variable.

Note 9. Ritter (1984) and Krinsky and Rotenberg (1989) report a positive relation between accounting data prior to issuance and IPO firm value.

Note 10. The impact of the variable Equity Retained on underpricing is mixed when used in stochastic frontier models. On the one hand, Hunt-McCool et al. (1996) report a positive relationship between equity retained and estimated offer price. On the other hand, Chen et al. (2002) and Reber and Vencappa (2016) do not find a statistically significant relationship. 
Note 11. Our findings are robust even if we control for another proxy to measure pre-issue demand for the IPO, calculated as the final offer size divided by the first filed offer size as suggested in Goldstein et al. (2011). To save space, we do not report this result.

Note 12. There is an asymmetry in the bankers' expected profits as the result of the SEC institutional constraint which prohibits adjusting the offer price ex post to clear the primary market and the uncertainty about the exact realization of demand for the issue (Marchard \& Roufagalas, 1996)

Note 13. In the case of Multiple Lead Underwriters, we consider the relationships between all the banks and institutional investors.

Note 14. We performed a manual correction of underwriters' data because multiple variations of the same underwriters' names appeared in the original dataset.

\section{Copyrights}

Copyright for this article is retained by the author(s), with first publication rights granted to the journal.

This is an open-access article distributed under the terms and conditions of the Creative Commons Attribution license (http://creativecommons.org/licenses/by/4.0/). 